УДК 332.12+911.372:338.138+659.4

DOI: 10.24144/2078 - 1431.2019.2(23).127-134

Михайло Газуда,

доктор економічних наук, професор, професор кафедри економіки та підприемництва

Мирослава Стеців, аспірантка кафедри економіки та підприемництва ДВНЗ «Ужгородський національний університет»

\title{
СУЧАСНИЙ СТАН І ТЕОРЕТИКО-МЕТОДОЯОГІЧНА ОСНОВА РОЗВИТКУ БРЕНДИНГУ ТЕРИТОРІЙ
}

У статті досліджено теоретико-методологічні підходи до визначення поняття брендингу територій та сучасний стан його інтерпретац̧ї у вітчизняній економічній науці. Виявлено основні сутнісні відмінності цъого поняття від суміжних, описано можливі підходи до моделювання та визначення соціально-економічної изінності бренду території.

Ключові слова: брендинг, територія, брендинг територї, імідж територї, регіональний розвиток.

This article reveals separate aspects of studying the theoretical and methodological basis of the concept of branding on the example of territorial branding. Different approaches to the learning of a concept are characterized,isolation of the concept and key differences from related scientific categories by foreign and domestic scientists. The indicators of socio-economic value of the territory brand are described and one of the concepts of their calculation is outlined. As part of the writing the article the positive influence of branding on regional development and the creation of «points of economic growth» ware identified and determined, that branding of territories is a strategically important prerequisite for economic success of the region and its business, given the tendencies of in creasing competition through economic globalization, active development of the tourism sphere, activation of the very concept of branding territories in Ukraine and the real need to develop a system of support for local producers of goods and services for their diversification and looking for new ones, including foreign markets. The issue of development of territorial branding for organizations of different directions and forms of ownership is emphasized, because territorial branding is the right and most effective tool for the development of stability in the regions, increasing the competitiveness of goods and services, enhancing internal and attracting external resources.

Keywords: branding, territory, territory branding, territory image, regional development.

Дослідження новітніх методів та методик щодо сприяння місцевому розвитку, стратегї формування розвитку територій, проблематики позиціонування регіонів у рамках загальної конкуренції стали найглобальнішими векторами управлінської науки. Дотримання балансу в розвитку регіо- 
ну, логічне використання місцевих ресурсів задля забезпечення комплексного розвитку та високого рівня життя місцевого населення, підвищення конкурентоспроможності регіонів перебуває у прямій залежності від рівня ефективності маркетингових комунікацій та розвиненості брендингу в межах території. Територіальна конкуренція на сучасному етапі - це, перш за все,інвестиційний ринок, ринок праці, туризм та сфера послуг, які у разі ефективного застосування регіонального брендингу здатні перетворювати навіть найдепресивнішу місцевість на локальне «економічне диво» та позитивно впливати на самоідентифікацію населення,бажання людей жити і працювати у цій місцевості.

Аналіз останніх досліджень та публікацій. Теоретичні та практичні засади брендингу територій широко представлені у працях вітчизняних та зарубіжних науковців. Зокрема, найбільш широко тематику розкрито у працях Ф. Котлера, К. Асплунда, Д. Хайдера, І. Рейна, Д.Візгалова, П. Берга, С. Девіса, М. Кавараціса, Н. Котова, С. Зенкера, А. Аукареллі, Н. Мартіна, А. Моргана, Х. Різенбека, Б. Якобсена, I. Березіна. Найгрунтовнішими, 3 точки зору авторів, є праці С. Анхолта, що є основним творцем терміну «placebrending» і з 1998 року постійно публікує наукові праці, присвячені різним аспектам брендингу територій. Поруч із працями Ф. Котлера, у яких вперше було обумовлено визначення території як товару,ці наукові засади стали поштовхом до розвитку великої кількості суміжних понять, відомих у вітчизняній науці як регіональний брендинг, брендинг місць, брендинг територій тощо.

Метою статті є вивчення та характеристика теоретико-методичної основи брендингу територій. Для реалізації мети було поставлено такі завдання:

1) розглянути ключові підходи до вивчення поняття «брендинг»;

2) визначити місце бренду в структурі територіального брендингу;

3) виокремити сутнісні ознаки,цінності та моделювання брендингу територій.

Виклад основного матеріалу. Загальне поняття брендингу, що наразі займає вагоме місце в управлінській та політичній науках,має грунтовну економічну підоснову, адже метою брендингової діяльності є збільшення рівня доданої вартості продукту та отримання прибутків від створення бренду. Зважаючи на це,варто відзначити, що брендинг як наука створення i просування торгових марок задля формування для них довгострокових переваг, поступово стає ключовою проблематикою економічної науки.

Відомий дослідник брендингу П. Темпорал зазначає, що наразі брендинг може претендувати на виділення його як самостійного виду діяльності, оскільки виробляе та постачає конкурентоспроможні продукти на особливий ринок торгових марок та здійснюе управдіння ними в якості інструменту, що відіграє провідну роль в забезпеченні успішності бізнесу в майбутньому. У процесі брендингу бренд, як його кінцевий продукт, є сутністю, що розвивається від концепції, що відома покупцеві та складається з елементів (фірмової назви, стилю, слогана) до сукупності емоцій і смислів, що стосуються і самого товару, і способу його подання. У сучас- 
ній економіці брендинг стає дедалі популярнішим як нова галузь знань та галузь практичної діяльності. П. Темпорал також зазначає, що брендинг - це весь складний маркетинговий процес творення бренду, його відповідної юридичної реєстрації та управління[7].

Закономірно, що основним матеріальним продуктом регіонального брендингу є бренд. Аналізуючи підходи до визначення поняття бренду, перш за все потрібно відзначити, що єдиного його трактування в сучасній економічній науці не існує. Навіть попри те, що провідні спеціалісти, такі, як Девід А. Акер, заслужено вважають, що «XXI ст. - епоха створення брендів», вчені досі не мають єдиного понятійного апарату у цій сфері, а відтак у своїх дослідженнях відображають наукову категорію по-різному. Зокрема, розглядаючи поняття у лінгвістичному векторі, бренд - це клеймо, спосіб ідентифікації продукції; для маркетологів - сума якостей товару, які роблять кожну окрему купівельну пропозицію унікальною та впізнаваною; для стратегів - засіб управдіння відносинами між організацією та иї цільовою аудиторією[4].

Багато українських науковців схильні трактувати бренд як товарний знак, котрий вже здобув популярність, уособлює довіру покупця завдяки тому, що підприємство веде правильну маркетингову стратегію. На підтвердження такого підходу до трактування варто відзначити, що в цьому ж напрямі бренд вивчає багато іноземних маркетологів та економістів. Зокрема, Чарльз Брумер, генеральний менеджер компанії InterbrandSchecter,визначив поняття бренду так: «Бренд - це дещо більше, ніж реклама та маркетинг. Це все, що приходить людині на розум стосовно продукту, коли вона бачить його логотип чи чує назву»[5].

На початку XXI століття в економічній науці започатковано активне дослідження регіону як окремої адміністративної, соціально-економічної та географічної одиниці. Відповідно на перший план досліджень вийшли питання забезпечення збалансованого регіонального розвитку, створення центрів економічного розвитку регіонів, доцільності інфраструктурних інвестицій та стратегій, збуту регіональної продукції. На практиці при взаємодії цих напрямів та їх паралельному дослідженні вчені пропонують дедалі глибше застосовувати технологіі регіонадьного брендингу. Відомий ідеолог та дослідник у галузі брендингу С. Анхолт відзначає, що територіальний брендинг - це акт просування та обміну, в якому не потрібно вбачати самоціль, це можливість створення іміджу, репутації країни або міста [1]. Відповідно, на думку автора, територіадьний брендинг найбідьш доцільно розгдядати з точки зору прагнення створення додаткової вартості для регіональних товарів, популяризації території, як сприятливої для інвестування, підприємництва та життя громадян, розставдяння акцентів на перевагах кожного окремого регіону. Сутність цієї концепції відображена у шестикутнику Анхолта (рис. 1).

Схожі твердження можна прослідкувати у визначеннях поняття «брендинг території», укладених багатьма іншими відомими науковцями. Зокрема Т. Атаєва окреслює бренди території як бренд країни, міста чи іншого територіального утворення, що е впливовим чинником просу- 
вання території, спирається на ії потенціал та ресурси, а також на бренди товарів і послуг, осередком яких є визначена географічна місцевість. Ф. Го визначає територіальний брендинг як процес визначення ресурсів, що для більшості територій є їх найціннішим активом. К. Дінні вважає, що територіальний брендинг - це творення «найреалістичнішого, найконкурентоспроможнішого й стратегічного бачення міста, регіону чи країни. Схожу думку мають дослідники А. Брусова та І. Щепіна, які зазначають, що брендинг території - це образ регіону у свідомості світової громадськості [6].

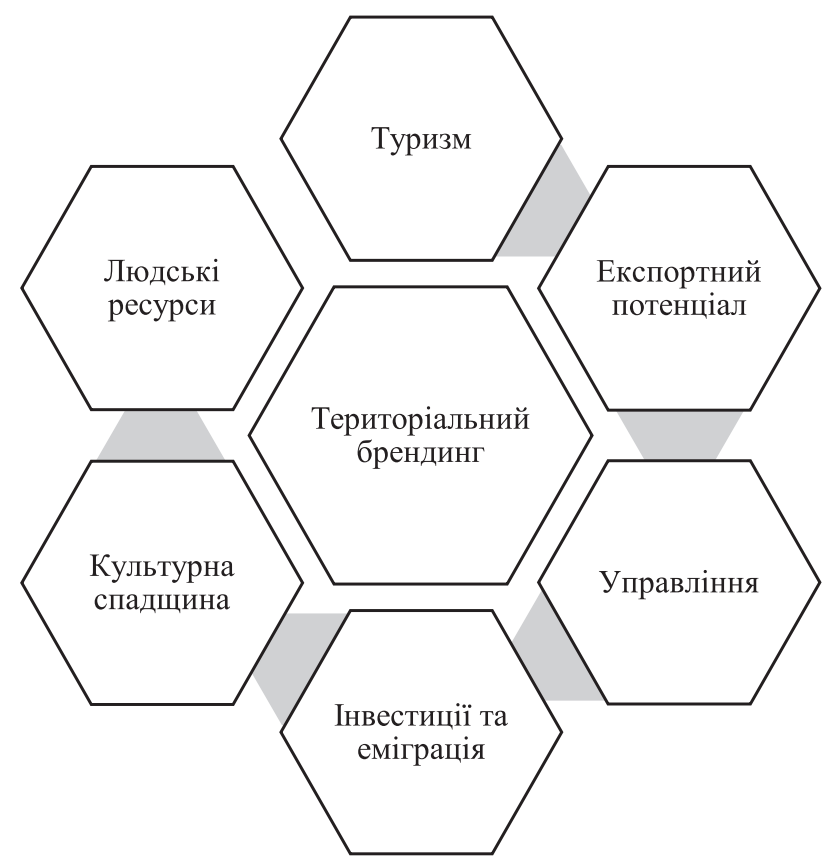

Рис. 1. Брендинг у системі маркетингу територій [1]

Зараз серед науковців дедалі частіше зустрічаються твердження, що на сучасному етапі відбувається чітке зміщення геополітичного суперництва в економічну сферу, що у свою чергу зумовило появу поняття «економіка цінностей». На думку більшості авторів, перехід до економіки цінностей означає те, що як у масштабах країни, так і на міжнародному рівні відбувається відхід від стандартної серійно-товарної економіки до економіки ексклюзивності, в якій ключову роль відіграватиме саме бренд.

М. Бойко, аналізуючи та підсумовуючи багато позицій вчених щодо сутнісних ознак бренду, відзначає, що організаційно-економічний механізм формування національного бренду є системою методів, способів та прийомів, які повинні забезпечити сприйняття національного бренду як симводічного капіталу (факт наявності бренду як символу території) та капіталу у класичному розумінні (ринкова вартість бренду та доходи від його використання) об'єктами внутрішнього і зовнішнього середовища. Вчений пояснює, що невід'ємним атрибутом сучасної економіки є символічний капітал, який додає товарам чи послугам унікальності, важливості та індивідуальності, а отже, закономірно, вартості. Ддя сучасної економіки 
надзвичайно важливо не лише володіння інформацією, а чітка демонстрація наявності формально виражених якостей у вигляді знаків та символів[2].

М. Бойко також зазначає, що територіальний бренд є географічно маркованим, відповідно його місією є відображення глобальної геополітичної або націонадьної місії, що відповідно зумовлює потребу якомога повнішого врахування усіх показників, що обумовлюють соціально-економічну цінність бренду території (регіону). Ці показники узагальнені у таблиці та формалізовані у функції виду:

$$
\mathrm{VTB}=\mathrm{F}(\mathrm{FU}, \mathrm{E}, \mathrm{SC}, \mathrm{NH}, \mathrm{I}, \mathrm{RS})
$$

Таблицุя 1

Кдючові показники соціадьно-економічної цінності бренду території за М.Бойком [2]

\begin{tabular}{|c|c|}
\hline Кдючові показники & Характеристика показників \\
\hline Функціонадьність (FU) & Умови, що визначають вартість і якість життя громадян \\
\hline Емоційність (Е) & Емоції, які викликає бренд території \\
\hline $\begin{array}{c}\text { Соціально-культурне } \\
\text { сприйняття (SC) }\end{array}$ & $\begin{array}{c}\text { Освіченість та толерантність населення, територіальна } \\
\text { субкультура }\end{array}$ \\
\hline $\begin{array}{c}\text { Духовно-історичне } \\
\text { сприйняття (NH) }\end{array}$ & Сприйняття історичного та релігійного спадку \\
\hline території
\end{tabular}

Відповідно до тенденцій міжнародної економіки, позитивний вплив брендингу на регіональний розвиток та утворення «точок економічного зростання» було відзначено Національним інститутом стратегічних досліджень України. Саме завдяки бренду території збільшується іiі відвідуваність, формується регіональна індустрія промислів, послуг та розваг. Цілком логічно, що кожна територія намагається знайти своє унікальне обличчя та зайняти місце у свідомості зацікавлених груп (населення, споживачів, туристів, інвесторів), сформувати конкретну ідентичність, що дозводить їй бути конкурентною у тривалому період. С.С. Велещук вбачає у брендуванні територій ключовий пріоритет регіонального розвитку України та наголошуе на потребі врахування цього у стратегіях соціально-економічного розвитку регіонів. Актуалізацію питання брендування він обумовлюе тенденціями зростання конкуренції в умовах глобалізації світової економіки, конкуренції між регіонами, активного розвитку сфери туризму, активізації концепції орендування українських територій, необхідності розвитку системи підтримки місцевих виробників товарів та послуг, особливо при експорті їх товарів за межі території [3]. 
Потрібно відзначити, що тематика регіонального брендингу є надзвичайно широкою, адже може включати в себе брендинг як місцевості загалом, так і брендування продукції, що виробляеться у межах регіону, унікальних кліматичних умов, особливостей природи, народних промислів, надання унікальних послуг тощо. Сучасні літературні джерела пропонують достатню кількість різних моделей творення брендів, однак, на думку авторів, найбільш доцільним є акцентувати увагу на двох базових брендингових концепціях: англо-американській (західній) та японській (східній).Їх ключова відмінність визначаеться тим, що західна модель грунтується на психологічних особливостях та характеристиках, при їі використанні дуже точно прописують емоційну складову. Натомість східна концепція запоруку успіху вбачає у капіталі та інвестиціях як найважливіших аспектах якості бренда. Відповідно, якщо західна модель виводить на ринок кілька лінійок чи продуктів, кожен $з$ яких є індивідуальним брендом, а споживачі часто навіть не підозрюють про спідьне походження кожного з цих товарів, то ключовим лозунгом японської моделі є успіх та сталий імідж одного бренду, який може бути виробником інших підбрендів. У векторі регіонального брендингу для виробників місцевої продукції чи сфери послуг, на нашу думку, більш доцільно використовувати засади західної концепції, адже, зважаючи на певну кількість умов та ресурсного потенціалу регіону, в межах одної території повинні розвиватися виробничі та невиробничі бренди різного роду, кожен з яких є повноцінним та незалежним від іншого. Натомість дотримуватися японської моделі варто у формуванні іміджу території та політичному брендингу регіону.

Висновки $з$ проведеного дослідження. Сучасні ринкові умови трактують жорсткі правила конкуренції та сприяють постійному вдосконаленню різних економічних суб'єктів. Відповідно змінюється і підхід до дослідження та управління територіями і територіальним розвитком зокрема. Відомі та популярні для країн з перехідною економікою моделі уже не відповідають на потужні викдики сучасності та не допомагають територіям процвітати в умовах глобалізації, капіталізації, вільних економічних зон, активізації міжнародної торгівді, зростанні активності та міграції населення. Регіон поступово стає товаром, виконуе не тільки адміністративну та культурну роль, а й нагромаджуе своєрідні нематеріальні активи.

Безумовно, для збільшення можливостей розвитку та створення умов, сприятливих для життя населення,місцевим підприємцям та органам місцевого самоврядування варто чітко усвідомлювати актуальність формування брендингу територій та стратегічного планування регіонального розвитку. Досвід розвинених країн свідчить, що саме практичне застосування брендингу забезпечує економічних суб'єктів території необхідним рівнем навичок для залучення інвесторів і потенційних жителів, формує чітку стратегію позиціонування місцевості на локальному та міжнародному ринках, допомагає бізнесу розширювати збут та диверсифікувати виробництво.

На сучасному етапі брендинг території - правильний та найбільш ефективний інструмент процесу управління та розвитку сильного і ста- 
більного регіону. Це зумовлено тим, що територія, яка володіє притаманними бренду рисами,швидше та з більшою ймовірністю успіху збільшує конкурентоспроможність товарів та послуг, виготовлених в їі ареалі, активізує внутрішні та постійно залучає зовнішні ресурси, краще будуе стосунки між бізнесом та органами державного й регіонального управдіння, котрим, у свою чергу, небайдуже щодо престижу та процвітання підпорядкованих їм територій.

Безумовно, варто відзначити, що цей вектор досліджень є новим для економічної науки та знаходиться на стадії активного формування, а понятійний апарат категорії брендингу наразі досить широко інтерпретується і потребує формування сталої і чіткої системи. Таким чином, тематика теоретико-методологічної основи розвитку брендингу територій постійно актуалізується, а подальші наукові дослідження можуть спрямовуватися як на пошук практичних альтернатив, так і на детальніше вивчення фундаментальних теоретичних засад та понять.

\section{СПИСОК ВИКОРИСТАНИХ ДЖЕРЕ}

1. Anholt, S. Competitive Identity: The New Brand Management for Nations, Cities and Regions / S. Anholt. 1st edition. PalgraveMacmillan, 2007. 160 p.

2. Бойко М.Г. Організаційно-економічний механізм формування національного бренду // Теоретичні та прикладні питання економіки. - 2010. - Вип. 21. - С. 304311.

3. Велещук С.С. Територіальний брендинг як інструмент соціально-економічного розвитку регіону // Сталий розвиток економіки. - 2015. -№13. - С. 146-152.

4. Карачина Н.П. Етимологія та розвиток трактування економічної категорії «бренд» //2017. PhDThesis.BHTУ.URL:http://ir.lib.vntu.edu.ua/bitstream/handle/123456789/17109/3025.pdf?sequence=3.

5. Кузьмук О. Територіальний брендинг як інструмент місцевого розвитку // Вісник Львівського університету, Серія філос.-політологія. Студії. - 2018. - С. 156 - 161.

6. Панасенко И. Брендинг території: сучасна парадигма розвитку // Схід. - 2014. C. 78-84.

7. Темпорал П. Эффективный бренд-менеджмент: пер. с англ. / СП-б: Нева, 2016. 286 c.

\section{REFERENCES}

1. Anholt, S. (2007) Competitive Identity: The New Brand Management for Nations, Cities and Regions / S. Anholt. 1st edition. Palgrave Macmillan,160[in English].

2. Boyko, M.H. (2010). Orhanizatsiyno-ekonomichnyy mekhanizm formuvannya natsional'noho brendu [Organizational and economic mechanism of national brand formation]. Teoretychni ta prykladni pytannya ekonomiky - Theoretical and applied issues of economy, 21,304-311 [in Ukrainian].

3. Veleshchuk, S.S. (2015). Terytorial'nyy brendynh yak instrument sotsial'no-ekonomichnoho rozvytku rehionu. [Territorial branding as a tool for socio-economic development of the region]. Stalyy rozvytok ekonomiky - Sustainable economic development, 13, 146-152 [in Ukrainian]. 
4. Karachina, N.P. (2017). Etymolohiya ta rozvytok traktuvannya ekonomichnoyi katehoriyi «brend» [Etymology and development of interpretation of the economic category «brand»]. PhD Thesis. VNTU. Retrieved fromhttp://ir.lib.vntu.edu.ua/bitstream/ handle/123456789/17109/3025.pdf?sequence=3[in Ukrainian].

5. Kuzmuk, O. (2018). Terytorial'nyy brendynh yak instrument mistsevoho rozvytku [Territorial branding as a tool for local development].Studiyi - Studios, 156 - 161 [in Ukrainian].

6. Panasenko, L. (2014) Brendynh terytoriyi: suchasna paradyhma rozvytku [Branding of the territory: the modern paradigm of development]. Skhid - East, 78-84 [in Ukrainian].

7. Temporal, P. (2016). Efektyvnyy brend-menedzhment: per. s anhl. [Effective brandmanagement: trans. with English]. SP-b: Neva [in Ukrainian]. 